\title{
Miranda
}

Revue pluridisciplinaire du monde anglophone /

Multidisciplinary peer-reviewed journal on the English-

speaking world

$11 \mid 2015$

Expressions of Environment in Euroamerican Culture / Antique Bodies in Nineteenth Century British

Literature and Culture

\section{Exhuming the Vestigial Antique Body in Walter Scott's Caledonia}

\section{Céline Sabiron}

\section{(2) OpenEdition}

1 Journals

Electronic version

URL: https://journals.openedition.org/miranda/6694

DOI: $10.4000 /$ miranda.6694

ISSN: 2108-6559

Publisher

Université Toulouse - Jean Jaurès

\section{Electronic reference}

Céline Sabiron, "Exhuming the Vestigial Antique Body in Walter Scott's Caledonia", Miranda [Online], 11 I

2015, Online since 20 July 2015, connection on 08 September 2022. URL: http://

journals.openedition.org/miranda/6694 ; DOI: https://doi.org/10.4000/miranda.6694

This text was automatically generated on 8 September 2022.

\section{(c) (i) () $\Theta$}

Creative Commons - Attribution-NonCommercial-NoDerivatives 4.0 International - CC BY-NC-ND 4.0

https://creativecommons.org/licenses/by-nc-nd/4.0/ 


\title{
Exhuming the Vestigial Antique Body in Walter Scott's Caledonia
}

\author{
Céline Sabiron
}

1 In Walter Scott's Border Antiquities of England and Scotland (1814-1817), the AngloScottish border is portrayed as a backbone ${ }^{1}$ connecting the English and Scottish limbs of the British body, and lying there, almost lifeless, for two centuries since the Union of the Crowns:

The frontier regions of most great kingdoms, while they retain that character, are unavoidably deficient in subjects for the antiquary. [...] The case becomes different, however, when, losing by conquest or by union their character as a frontier, scenes once the theatre of constant battle, inroad, defence, and retaliation, have been for two hundred years converted into the abode of peace and tranquillity [...]. Numerous castles left to moulder in massive ruins; fields where the memory of ancient battles still lives [...],- - unite to render these regions interesting to the topographical historian or antiquary. This is peculiarly the case on the border of Scotland and England ${ }^{2}$.

2 It is this now peaceful border country strewn with entombed Antique bodies which Scott wishes to burrow into and reanimate in his early non-fictional work ${ }^{3}$, as well as in his historical novels. Scott's antiquarian posture is particularly fecund in Guy Mannering (1815) and above all The Antiquary (1816) which are the main focus of this article as they both display his appetite for the last vestiges of the past, through allusions to classical Rome in Guy Mannering (GM II, 1: 118), or the use of a late $18^{\text {th- }}$ century stereotype and parodic embodiment of the Antiquary in his eponymous novel. Projecting himself onto the character of Jonathan Oldbuck from Monkbarns-a near-synonym of Abbotsford ${ }^{5}-$, Scott is fascinated by the Antique body (whether military, civic or cultural) which has been imprinted onto the Scottish landscape since the Roman conquest.

3 His very strong interest in Antiquity is symptomatic of $18^{\text {th }}$-century writers, and of Scottish ${ }^{6}$ ones in particular. "Antiquarianism in Scotland was a state of mind, a place of refuge, and a national and nationalistic hobby", writes Richard Humphrey in his study of Waverley ${ }^{7}$. Roman antiquarianism was particularly popular in both England and Scotland in the early- to mid- $18^{\text {th }}$-century even nicknamed the "Augustan age" as it 
served to feed patriotism. Analogies were often drawn between the Roman Empire and the new expanding British Empire. While the English used antiquarianism to highlight England's hegemonic power through its link to ancient Rome, the Scots mostly referred to it to bring out the internal colonisation ${ }^{8}$ of their country merged, through an unholy union, with its Siamese twin. The Hanoverian army, which was busy in the north wiping out any armed rebellions after the Jacobite Risings, was often compared to the Roman army which had tried, only in vain, to pacify and gain control of Caledonia, the land beyond the frontier, north of Hadrian's and Antonine's Walls erected between 122 and 142. Taking pride in its strong resistance to the Romans' repeated assaults, Scotland, or Caledonia, has used this lineage to show its legitimacy through its long history, to build its identity as a powerful nation, and to write its own romance of restoration.

Walter Scott's Scottish novels therefore partake of the 18th-century Romantic wish to exhume the corporeal Antique body of Scotland-a body which is altogether nostalgically reconstructed and satirically deconstructed through a constant tension between the author's attraction for the Romans' cultural and linguistic grandeur and his repulsion for their unbridled imperialism. Guy Mannering and The Antiquary both articulate a shift from Roman Antiquity to Scottish modernity, which is also a move away from nationalism to focus on humanity. The strong, almost unconquerable body of the nation inherited from the Roman Empire seems to give way to the more perishable and fallible Scottish human body. Scotland's Roman model is eventually written off to be replaced by Scott's "Caledoniad", a Scottish national epic made up of a fragmented textual body, which Lovel, or Lord Geraldine, from The Antiquary is supposed to be clandestinely writing.

5 Following the Romantic fascination for history and in particular the classical past, Walter Scott's novels highlight the traces of the Roman conquest which scar Scotland's body, thus showing its history of fighting, as well as its past grandeur and majesty. The memory of the invasion is imprinted on the Scottish landscape. The Borders are particularly marked by the vestiges of Roman fortifications built on the edge of the Imperium Romanum to close off the Limes which extend as far as the province of Britannia between the 1st and 4th centuries. In Guy Mannering Henry Bertram is taken off the beaten track so he can admire the vestiges of Hadrian's Wall, or Limes Britannicus. "Part of Brown's view in chusing that unusual track which leads through the eastern wilds of Cumberland into Scotland, had been a desire to view the remains of the celebrated Roman Wall, which are more visible in that direction than in any other part of its extent" (GM II, 1: 118). Out of dramatic concern, Scott chooses to position his character so that the lines marking the former Roman border are accentuated and even magnified through a close-up. The Antiquary Jonathan oldbuck and his friend Sir Arthur Wardour hint at a second wall erected to support Hadrian's Wall when they question the Saxon or Roman etymology of the Pictish word "Penval", meaning "caput valli" (A I, 6: 48) in Latin, i.e. "[t]he head of the wall" (49). It refers to the end of this additional construction according to Bede's Historia Ecclesiastica Gentis Anglorum quoted by the two friends. By exhibiting these relics of the past, located in a liminal space and at the margin of history after the fall of the Roman Empire, Scott's aim is once again to exhume the Antique body in order to bring it back to the centre of the map and to the surface of the earth. 
Under 18th-century Romantic "Scott-land", lie the remains of Roman Scotland which the Antiquary longs to excavate as he walks around with "Sandy Gordon's Itinerarium Septentrionale, a book illustrative of the Roman remains in Scotland" (A I, 1: 10) in his hand, and "plung[es] [...] into a sea of discussion concerning urns, vases, votive altars, Roman camps, and the rules of castrametation" (A I, 1: 10). Echoing the vertical layering of social development described by some thinkers of the Scottish Enlightenment, this geological stratification serves as a metaphor for a chronological cutting of palimpsest-like Scotland, with the intrepid time traveller seeking to reach the seabed and thereby the origins of the country. The very manly ("Oldbuck"; my emphasis) explorer of Antique vestiges leads his fellow-traveller, Lovel alias Lord Geraldin, through a new version of the Grand Tour transplanted into the wild indigenous Scottish soil for a greater appreciation of the vestiges from Antiquity. The stagecoach acts as a time machine so that the travel through space is in fact a journey through time. After "shewing his companion a Pict's camp or Round-about" (A I, 1: 10), Jonathan Oldbuck resumes his investigation in a little orchard near his property where he situates the extremity of the first Roman breakthrough after the Battle of Mons Graupius led by the General and Governor of the island, Julius Agricola, in about 84 . Despite the great division between Scottish antiquaries about the "local situation of the final conflict between Agricola and the Caledonians" (A I, 4: 28), the conceited collector of antiquities claims the traces of Roman remains are all but too blindingly obvious:

...is not here the Decuman gate? and there, but for the ravage of the horrid plough, as a learned friend calls it, would be the Praetorian gate.- On the left hand you may see some slight vestiges of the porta sinistra, and, on the right, one side of the porta dextra well nigh entire. Here, then, let us take our stand, on this tumulus, exhibiting the foundation of ruined buildings - the central point-the Praetorium, doubtless, of the camp. From this place, now scarce to be distinguished but by its slight elevation and its greener turf from the rest of the fortification, we may suppose Agricola to have looked forth on the immense army of Caledonians. (A I, 4: 29-30)

7 And yet, the Antiquary only points at what is missing in a Scottish landscape deprived of any Antique objects as illustrated by the oxymoron "indistinctly marked" (A I, 4: 27). His demonstration, based on suppositions ("we may suppose") rather than scientific evidence, mostly consists in conjuring up images of former Roman constructions. The traces have been erased by the passing of time, metaphorically embodied by the "horrid plough", an agricultural instrument widely used after major design improvements during the Industrial Revolution. Each alleged Roman gate only opens onto a blank materialised by a series of dashes, while the lexical field of scarcity ("some slight vestiges"; "now scarce to be distinguished") contrasts with the speaker's verbose monologue. What was meant to be a description of the Antique body of Scotland is only a figment of the backward-looking Antiquarian's imagination as shown by the use of a hypothetical "would". His "powers of vision" (A I, 4: 27) have nothing to do with seeing, but more with fantasizing ("we must have a vision"; A I, 14: 108). His early portrait thus features him with "a huge and antique gold repeater" (A I, 1: 7), a watch already hinting at his visual impairment.

In Scott's novels, the Antique body is exhumed and then buried again, after which the vestiges of the Roman past lose all their grandeur and decorum. They are antique indeed, mostly archaic and obsolete when they are not fake ("miscellaneous trumpery"; A I, 3: 22). They turn out to be useless artefacts, dust traps piled up in the Antiquary's mausoleum-like study: a "sanctum sanctorum" (A I, 3: 19, 20) or an unhealthy den, 
"obscurely lighted", with a "thick atmosphere". Jonathan Oldbuck fears any sort of profanation of this gloomy sepulchre in honour of the God of Antiquity; the latter being embodied by a large black cat compared to the serpent-shaped genius loci of Roman mythology. Intruding cleaners armed with tubs and dusters (20-21) are seen as sacrilegious in that they imperil the preservation of the Antique body. In Possible Scotlands: Walter Scott and the Story of Tomorrow, Caroline McCracken-Flesher refers to these vestigial remains, "busts, and Roman lamps and pateræ" (21), as "detritus of the past ${ }^{9 "}$. Unrooted and displaced, they lay there, meaningless, and in a complete state of chaos. Covered in ancient poisonous dust ${ }^{10}$, they convey a feeling of morbidity increased by the risk of injury over "some piece of Roman or ancient British pottery" (22).

9 Scott's satirical treatment of the Antique body goes as far as to present the characters' sometimes "eroticized relationship to the material remnants of the past ${ }^{11}$ ". The characters' encounters with Roman vestiges are often imbued with erotic overtones. In a grotesque fall from the noble to the vile, the spiritual to the material, the human sexual body takes over the Antique body characterised by its gravitas, icy majesty and aristocratic grandeur. The Roman military conquest is reenacted in the form of a parody when Scottish soldier Henry Bertram and his companion Dandie Dinmont penetrate Scotland through the Maiden Way, a "sort of rugged causeway so called, being the remains of an old Roman road" (GM II, 2: 127), built along Hadrian's Wall by General Agricola to link up Corbridge with Carlisle: "I am informed that I can easily enter Scotland" (GM I, 2: 115), says Henry Bertram, in a state of sexual excitation (or erection). He is portrayed with "his firm step, his erect and free carriage" (GM II, 1: 117; my emphasis). The hymen ${ }^{12}$ - both in the sense of a union, a marriage, and a membrane protecting a woman's virginity-is then represented by Hadrian's Wall, which Henry immediately explores upon arrival. The character's "way lay through a wide tract of black moss, extending for miles on each side [of the wall] and before him" (GM I, 1: 3). Already taken by his fellow soldier Guy Mannering before, the crossing is presented as a sexual penetration: the verb "extend [...] into" highlights the dilatation and exploration of the phallus through the pubic mane ("wide tract of black moss"), and then the hymen. The sexual act ("lay") features as both a rape and an incest ("sister country"). Yet, like an old lover, the vestiges from a bygone age are soon neglected as Henry suddenly "remember[s] he was hungry" (GM II, 1: 118). This ironic punch line brings about the sterility of the character's excitation which amounts to onanism, and his failure to confront history and grasp the meaning of the Antique body. The erotic body is thus superseded by an insatiable Rabelaisian body eating and drinking, with the image of Jonathan and Lovel toasting over red wine and cake (A I, 4: 26) in the middle of the sacred temple dedicated to Antiquity.

In Scott's novels, the Antique body is the object of a constant form of reconstruction. Belonging to a static past, it seems to lose its appeal in a modern, fast-changing country like Scotland. Some old pioneer paths were renovated but a lot of new military roads and bridges were built in the 1720 s and 1730 s by General Wade to stifle the Jacobite Risings and pacify the last rebellious clans. These new constructions crisscross the Scottish body and replace the Antique body, to the writer's satisfaction as he pays tribute to this progress under the mask of the anonymous poet in his novella "The Highland Widow" (1827): "the substantial excellence of these great works-for such are the military highways in the Highlands-deserved the compliment of the poet, [...] who 
produced the celebrated couplet - 'Had you but seen these roads before they were made, / You would hold up your hands, and bless General Wade"' (HW I, 7: 72). And yet, Scott "persistently shows how the detritus of the past can be forged (I use the word advisedly) into a new future ${ }^{13}$ ". If the visit to Hadrian's Wall does not trigger off any civic lessons and moral fables of classical history often found in 18th-century writers like William Godwin, it raises questions about creativity and posterity:

'And this then is the Roman Wall,' said he, scrambling up to a height which commanded the course of that celebrated work of antiquity: 'What a people! whose labours, even at this extremity of their empire, comprehended such space, and were executed upon a scale of such grandeur! In future ages, when the science of war shall have changed, how few traces will exist of the labours of Vauban and Coehorn, while this wonderful people's remains will even then continue to interest and astonish posterity! Their fortifications, their aqueducts, their theatres, their fountains, all their public works, bear the grave, solid, and majestic character of their language; and our modern labours, like our modern tongues, seem but constructed out of their fragments.' (GM II, $1: 118$ )

11 Through this auto-referential passage Scott reveals his own meta-fictional reflection on literature, itself based on heterogeneous fragments of textual bodies from the past. He shares his personal opinion ("view") on literary writing through his own panegyric of the Roman body, celebrated ("the celebrated Roman Wall", "that celebrated work of antiquity") by no other than himself. The artistic creation ("executed"), thought of as a work of procreation, an altogether painful ("labour") and grandiose ("such grandeur") parturition, relies on "the remains" of the past. The detour via this vestigial Antique body serves as a pretext for the writer to tackle the genesis and future of a work of literature. This is clearly demonstrated by the gradual shift from questions of architecture-whether with a military ("fortifications"), pacific ("aqueducts") or even cultural ("theatres") and decorative ("fountains") aim-to issues about the beauty of the Latin language which impregnates all the Roman public constructions: "[O]ur modern labours, like our modern tongues, seem but constructed out of their fragments". The last words of Brown's monologue convey Walter Scott's opinion. He longs for "posterity" and wishes to leave as lasting and distinctive a mark, similar to the one left by the Roman demiurges who stand out from their French and Dutch successors ("Vauban and Coehorn"). Scott's corpus constantly refers to Antique textual bodies. The Antiquary is made up of a patchwork of quotations from Aristotle, that "gifted genius ${ }^{14}$ ", and mostly Horace, a strong defender of any form of balance and compromise. The Waverley novels feed on Horatian thoughts, just as the Oldbucks' family motto is inspired by the Roman lyric poet and philosopher's recommendations in his Odes ("On Steadiness and Integrity"; III.3.1) advocating both consistency and integrity: "see here his favourite motto, expressive of his independence and selfreliance, which scorned to owe anything to patronage, that was not earned by desert-expressive also of that firmness of mind and tenacity of purpose recommended by Horace - " (A I, 11: 85). The Antiquary proudly insists and then adds: "aequam servare mentem is the motto of our friend Horace" (A II, 4: 154).

Scott raises the question of novelistic writing as fragmentary; a textual body looking like a "bag of scraps ${ }^{15}$ ", a work created with the remains of former productions, fragments recovered from past masterpieces owing to a shortage of literary materials. In The Heart of Midlothian, the young lawyer Mr Hardie, one of Scott's personae, pieces back together an idea expressed in La Bruyère's Caractères $^{16}$ on the inevitable "gleaning" of snippets from the past: "[t]he inventor of fictitious narratives has to rack 
his brains for means to diversify his tale, and after all can hardly hit upon characters or incidents which have not been used again and again" (HM I, 1: 14-15). In Scott's novels, the image conveyed is that of a patchwork quilt-cum-textual body: "[i]t is an amorphous collection of pieces that can be joined together in an infinite number of ways [...] A quilt comprises two layers of fabric stitched together, often with a filler in between ${ }^{17 "}$. The main role of artistic creation seems to be limited to that of filling in an interstitial space in between the fragments.

13 And yet, a Scottish voice emerges from behind to act as a seam and bring all these varied textual bodies together. It stitches the fabric from the past, thereby giving it a new unity and texture:

A voice from behind interrupted [Jonathan's] ecstatic description-'Prætorian here, Prætorian there, I mind the bigging o't'. Both at once turned round, Lovel with surprise, and oldbuck with mingled surprise and indignation, at so uncivil an interruption. An auditor had stolen upon them, unseen and unheard, amid the energy of the Antiquary's enthusiastic declamation, and the attentive civility of Lovel. (A I, 4: 30)

14 The Scottish voice, embodied by the down-to-earth blue-gown beggar Edie Ochiltree whose surname highlights his corporeal, natural roots-the reference to the oak tree should be read as a symbol of durability - breaks with a form of civility ("so uncivil"; "attentive civility") and grandeur ("enthusiastic declamation") which is characteristic of the Antique body. It is transcended, and at the same time renewed, through the competing voices of the oral historian who relies on facts and of the learned idealist who focuses on a distorted reality embellished by the figments of his imagination. In the Scottish novels, these two voices merge and the notion of vision is to be understood less in the sense of "eyesight" ("I appeal to people's eye-sight"; A I, 4: 29) since most of the characters are symbolically blind, than in the sense of foresight, i.e. the imagination ("building theories out of premises"; A I, 14: 106). Scott's historical imagination, to echo the title of David Brown's book ${ }^{18}$, enables Scotland to rebuild itself, to turn its history into a story in which the vestigial Antique body serves as a major cardboard setting.

The Scottish novels therefore operate a shift from Roman times to romance. Their diegeses move away from the vestiges of the Roman body to the fragmentary textual body of the romance ${ }^{19}$ novel: "Romance reproduces itself as the figure of mediation and synthesis by turning contradiction into ambiguity, which provides a vital margin of refuge between fatal historical fact and extravagant spiritual impossibility ${ }^{20 "}$. The story of Caledonia is thus rewritten in "The Caledoniad" as an auto-referential mise en abyme and a symbolic representation of novelistic creation:

'What think you of a real epic?-the grand old-fashioned historical poem which moved through twelve or twenty-four books - we'll have it so-I'll supply you with a subject-The battle between the Caledonians and Romans-The Caledoniad; or, Invasion Repelled-Let that be the title-It will suit the present taste, and you may throw in a touch of the times.'

'But the invasion of Agricola was not repelled.'

'No; but you are a poet-free of the corporation, and as little bound down to truth or probability as Virgil himself-You may defeat the Romans in spite of Tacitus.'

'And pitch Agricola's camp at the Kaim of-what do you call it,' answered Lovel, "in defiance of Edie Ochiltree?' 
'No more of that, an thou lovest me-And yet, I dare say, ye may unwittingly speak most correct truth in both instances, in despite of the toga of the historian and the blue gown of the mendicant.' (107) (“[m]y principal amusements being literary" (A I, 14: 105), to write a fictionalized account of the ancient Caledonian battle in Scotland, with little attention paid to historical accuracy. The authority of both the great historian of the Roman Empire, Tacitus, and the Scottish bard is dismissed in the name of literary freedom. Arguing against any constraints, be they of content or form, Scott's persona in the novel claims that "[a] man may be a poet without measuring spondees and dactyls like the ancients, or clashing the ends of lines into rhyme like the moderns, as one may be an architect though unable to labour like a stone-mason-dost think Palladio or Vitruvius ever carried a hod?" (A I, 14: 107). Comparing the writer with a Roman architect, Oldbuck equates construction work with novelistic work. The architecture of the novel is made of Roman stones held together by a more modern and personalised cement. He decides to provide his narrator Lovel with historical notes which are symbolically placed outside the bounds of the main textual body: "think we may introduce the whole of the Essay on Castrametation into the appendix-it will give great value to the work. Then we will revive the good old forms so disgracefully neglected in modern times" (A I, 14: 108). Considered as essential but peripheral to the novelistic discourse, this informative documentation on the vestigial Antique body is not provided but only alluded to at the end of Scott's novel: "[Oldbuck] regularly inquires whether Lord Geraldin [alias Lovel] has commenced the Caledoniad, and shakes his head at the answers he receives. En attendant, however, he has completed his notes, which, we believe, will be at the service of any one who chuses to make them public, without risk or expence to THE ANTIQUARY" (A III, 16: 356). the novel, is Scott's Caledoniad which was published with historical and illustrative notes in 1816. "There was no need, finally, for Lovel to write his Caledoniad: a Caledoniad had already been brought to a successful conclusion in The Antiquary ${ }^{21 "}$. The Antique body raises questions of posterity and authorship. If the Antiquary is immediately ready to put his historical notes at the reader's disposition-as he is only the collector and conveyor of these fragments of the past -, he is much more cautious when it comes to acknowledging his paternity of the book for fear of public reaction ${ }^{22}$, like Scott publishing his novel anonymously. There is a constant dialogue between history and fiction, the vestigial Antique body and the contemporary literary and cultural body of Scotland. Scott's ironic criticism of authors ${ }^{23}$ illustrates this dialogue perfectly with references, for example, to Hector Boece-the first Principal of the University of Aberdeen and writer of a history of Scotland in Latin (Scotorum Historice, 1526) who made a list of Scottish kings, many of whom were imaginary, to prove the ancient standing of the Scottish monarchy-or James Macpherson-known as the "translator" of the Ossian cycle of poems, which he in fact invented and wrote himself-who falsified the truth to magnify Scotland, thereby turning it into a mythical and poetical Caledonia.

The 18th-century is marked by a "Romantic investment in the past ${ }^{24 "}$ ", especially the period following the French Revolution, the source of a radical break in history. Writing at the beginning of the $19^{\text {th }}$ century, Walter Scott feeds on this trend to re- 
imagine a Scottish identity after the country's union with its southern more powerful neighbour. To this end, he focuses on the vestigial Antique body of Caledonia and exhumes it from its soil in order to highlight Scotland's long and glorious past, in particular, its successful fights against the Roman invaders. In The Antiquary, he portrays the rise of the antiquarian sensibility with a strong attachment to objects and artifacts from the Roman era. With their clutter of details, antiquarians "concerned themselves with the past as recuperable only in ruined form, not as part of a chain of progress ${ }^{25}$ ", an expression which underlines the author's twofold position, between continuity and break with the Enlightenment promoting a "Chain of Being ${ }^{26 "}$. Scott's novel mocks the regressively naive and eccentric Roman antiquarianism. He chooses to ascribe fanciful significance to the Antique body just because it is antique, in the sense of old, while articulating a more continuous relationship to the past. Guy Mannering and The Antiquary transcend the Antique body, eroticized and replaced by a more modern Scottish body.

Eager to reject a scandalous invention of lost cultural origins, Scott uses the vestigial Antique body to redefine Scotland's roots in terms of a well identified past. Yet these fragments from the Roman era are nonetheless mixed with romance since Scott's historicism is based on a literary approach to historiographical practice as James Chandler points out in England in 181927. While Scott's ironic reconstruction of Antiquity announces late $19^{\text {th }}$ century stylistic restorations, the historical novel, fathered by Scott, becomes "the governing form of Western narrative for the next hundred years ${ }^{28}$. The Scottish novelist indeed helped create a new form of novel, which, like a patchwork, is made up of Scottish inventions, universal modernity and fragments from the national past. The Romantic body of "Scott-land" and its vestiges have now been turned into a commodity which modern tourists enthused by their reading of the Waverley novels, seek to rediscover in Scotland.

\section{BIBLIOGRAPHY}

Bann, Stephen. Romanticism and the Rise of History. New York: Twayne, 1995.

Brown, David. Walter Scott and the Historical Imagination. London: Routledge and Kegan Paul, 1979.

Chandler, James. England in 1819: The Politics of Literary Culture and the Case of Romantic Historicism, Chicago: Chicago UP, 1998.

Davis, Leith, Ian Duncan, and Janet Sorensen, eds. Scotland and the Borders of Romanticism. Cambridge : Cambridge UP, 2004.

Deleuze, Gilles and Félix Guattari. «Le Lisse et le strié ». Capitalisme et schizophrénie 2 : Mille Plateaux. Paris : Minuit, [1980] 2009.

Duncan, Ian. Modern Romance and Transformations of the Novel : The Gothic, Scott, Dickens. Cambridge: Cambridge UP, [1992] 2005. 
Dunnigan, Sarah, and Suzanne Gilbert, eds. The Edinburgh Companion to Scottish Traditional Literatures. Edinburgh: EUP, 2013.

Fielding, Penny. Scotland and the Fictions of Geography: North Britain, 1760-1830. Cambridge: Cambridge University Press, 2008.

Goode, Mike. "Dryasdust Antiquarianism and Soppy Masculinity: The Waverley Novels and the Gender of History". Representations. Vol. 82 No. 1, Spring 2003.

Hechter, Michael. Internal Colonialism: The Celtic Fringe in British National Development, 1536-1966. Berkeley: California University Press, 1975.

Hingley, Richard. The Recovery of Roman Britain 1586-1906: A Colony So Fertile. Oxford: Oxford University Press, 2008.

Humphrey, Richard. Scott: Waverley. Cambridge: Cambridge University Press, 1993.

La Bruyere, Jean de. Les caractères ou les moeurs de ce siècle. Paris: Lefèvre, [1696] 1843.

Macqueen, John. The Enlightenment and Scottish Literature: The Rise of the Historical Novel. vol. 2.

Edinburgh: Scottish Academic Press, 1982-1989.

Mccracken-Flesher, Caroline. Possible Scotlands: Walter Scott and the Story of Tomorrow. Oxford : Oxford UP, 2005.

Morere, Pierre. "L'Écosse au XVIIIe siècle : identité(s) territoriale(s) et désir d'universalité". "Territoires". XII-XVIII 66 (Automne 2009): 143-62.

Sachs, Jonathan. Romantic Antiquity: Roman in the British Imagination, 1789-1832. Oxford: Oxford University Press, 2010.

Scott, Walter. The Border Antiquities of England and Scotland; Comprising Specimens of Architecture and Sculpture, and Other Vestiges of Former Ages. Edinburgh: Constable and Co., 1814-1817.

-. Provincial Antiquities of Scotland and Picturesque Scenery of Scotland. 2 vols. London: J. and A. Arch, 1819-1826.

-. The Antiquary. Ed. David Hewitt. EEWN. Edinburgh: Edinburgh University Press, [1816] 1995.

-. The Antiquary. Ed. Nicola Watson. Oxford World's Classics, Oxford: Oxford University Press, 2002.

-. Guy Mannering.Ed. Peter Garside. EEWN. Edinburgh: Edinburgh University Press, [1815] 1999.

Trumpener, Katie. Bardic Nationalism: The Romantic Novel and the British Empire. Princeton:

Princeton UP, 1997.

\section{NOTES}

1. The Pennines are traditionally described as forming a relief "backbone", or spine. In his novels, Scott often portrays England and Scotland as two sisters ("her sister kingdom" The Black Dwarf I, 2: 14; "northern sister" The Heart of Midlothian III, 3: 249); hence the body metaphor.

2. Walter Scott, The Border Antiquities of England and Scotland; Comprising Specimens of Architecture and Sculpture, and Other Vestiges of Former Ages, Edinburgh: Constable and Co. , 1814-1817, iii-iv.

3. See also Walter Scott, Provincial Antiquities of Scotland and Picturesque Scenery of Scotland, 2 vols, London: J. and A. Arch, 1819-1826.

4. The titles of the novels have been abbreviated as follows: A: The Antiquary; GM: Guy Mannering; HM: The Heart of Midlothian; HW: "The Highland Widow". 
5. Walter Scott, The Antiquary, ed. Nicola Watson, Oxford World's Classics, Oxford: Oxford UP, 2002, xiii.

6. " 'Antiquarianism was a 'manly' pursuit, encouraging masculine qualities, whether it was through identification with the political virtue and patriotism of ancient Rome or the military glory and contempt for death evidenced by the Goths.' [...] In $18^{\text {th }}$ century Scotland, significantly, antiquarianism was integrally related to a contemporary desire to understand the nation and its meaning within the newly British context. After the Union of the Parliaments, antiquarianism offered a means to understand Scotland's past and, in the past, the present's foundations". Valentina Bold, "Eighteenth-Century Antiquarianism", in The Edinburgh Companion to Scottish Traditional Literatures, ed. Sarah Dunnigan and Suzanne Gilbert, Edinburgh: EUP, 2013, 86-87.

7. Richard Humphrey, Scott: Waverley, Cambridge: Cambridge UP, 1993, 25.

8. Michael Hechter, Internal Colonialism: The Celtic Fringe in British National Development, 1536-1966, Berkeley: California UP, 1975.

9. Caroline McCracken-Flesher, Possible Scotlands: Walter Scott and the Story of Tomorrow, Oxford: Oxford UP, 2005, 39.

10. "'you will be poisoned here with the volumes of dust they [the women] have raised,' continued the Antiquary, 'but I assure you the dust was very ancient, peaceful, quiet dust, about an hour ago, and would have remained so for a hundred years'" (A I, 3: 21).

11. Mike Goode, "Dryasdust Antiquarianism and Soppy Masculinity: The Waverley Novels and the Gender of History", Representations, 2003, 72.

12. Whereas in terms of manners the English are often portrayed as effeminate and the Scots as rough and virile, in particular in the Highlands, the gender bias is reversed when it comes to politics, the English gaining the upper hand and being described as powerful, and the Scots as weaker and forced into an unequal marriage with their neighbour: "the Act of Union appears as a forced marriage, undertaken against the bride's better judgment. 'Why Should I Be So Sad On My Wedding Day?' played the carillon of Saint Giles, Edinburgh, on the day of the Treaty of Union was signed". Katie Trumpener, Bardic Nationalism: The Romantic Novel and the British Empire, Princeton: Princeton UP, 1997, 134. Gender identities are presented as fluid and contrastive in Scott's novels.

13. Caroline McCracken-Flesher, Possible Scotlands: Walter Scott and the Story of Tomorrow, 39.

14. Walter Scott, The Miscellaneous Prose Works of Sir Walter Scott, "Essay on the Drama ", Edinburgh: Cadell and Co., 1827, 375.

15. « sac à chutes ». Deleuze, Gilles and Felix Guattari, " Le Lisse et le strié », Capitalisme et schizoprénie 2 : Mille Plateaux, Paris : Minuit, [1980] 2009, 594.

16. «Glaner. Tout est dit : l'on ne fait que glaner après les anciens et les habiles d'entre les modernes ». Jean de La Bruyère, Les caractères ou les mœurs de ce siècle, Paris : Lefèvre, [1696] 1843, 552.

17. "[c]'est une collection amorphe de morceaux juxtaposés, dont le raccordement peut se faire d'une infinité de manières [...]. On appelle quilt la réunion de deux épaisseurs de tissus piquées ensemble entre lesquelles on introduit souvent un rembourrage". Deleuze, Gilles and Félix Guattari, « Le Lisse et le strié », 595.

18. David Brown, Walter Scott and the Historical Imagination, London: Routledge and Kegan Paul, 1979.

19. In a 1822 supplement to The Encyclopedia Britannica, Scott himself defines the romance as "a fictitious narrative in prose or verse; the interest of which turns upon marvelous and uncommon incidents; being thus opposed to the kindred term Novel, which [...] we would rather define as a fictitious narrative, differing from the Romance, because the events are accommodated to the ordinary train of humane vents, and the modern state of society. Assuming these definitions, it is evident, from the nature of the distinction adopted, that there may exist compositions which it is 
difficult to assign precisely or exclusively to the one class or the other; and which, in fact, partake of the nature of both". Walter Scott, "Essay on Romance", The Miscellaneous Prose Works of Sir Walter Scott, vol. 6, Edinburgh: Robert Cadell and Co., 1843-71, 127.

20. Ian Duncan, Modern Romance and Transformations of the Novel: The Gothic, Scott, Dickens. Cambridge: Cambridge UP, [1992] 2005, 15.

21. John MacQueen, The Enlightenment and Scottish Literature: The Rise of the Historical Novel, vol. 2, Edinburgh: Scottish Academic Press, 1982-1989, 56.

22. "'I may, like a second Teucer, discharge my shafts from behind the shield of my ally; and admit that he should not prove to be a first-rate poet, I am in no shape answerable for his deficiencies, and the good notes may probably help off an indifferent text'" (A I, 14: 108).

23. "'in the notes I will have a hit at Boethius-No; I must not touch that topic, now that Sir Arthur is likely to have vexation enough besides-but I'll annihilate Ossian, Macpherson, and Mac-Cribb'" (A I, 14: 108).

24. Stephen Bann, Romanticism and the Rise of History, New York: Twayne, 1995, 9.

25. Susan Manning, "Antiquarianism, the Scottish Science of Man, and the emergence of modern disciplinarity", Scotland and the Borders of Romanticism, ed. Leith Davis, Ian Duncan, and Janet Sorensen, Cambridge: Cambridge UP, 2004, 64.

26. Alexander Pope, Essay on Man, 1734, VIII, Oxford: Clarendon Press, 1871.

27. James Chandler, England in 1819: The Politics of Literary Culture and the Case of Romantic Historicism, Chicago: Chicago UP, 1998, xv.

28. Leith Davis, Ian Duncan, and Janet Sorensen, eds, Scotland and the Borders of Romanticism, Cambridge: Cambridge UP, 2004, 3.

\section{ABSTRACTS}

Walter Scott's Scottish novels partake of the $18^{\text {th }}$-century Romantic wish to exhume the corporeal Antique body of Scotland-a body which is altogether nostalgically reconstructed as it is scarred by traces of the Roman conquest, and satirically deconstructed through a constant tension between the author's attraction for the Romans' cultural and linguistic grandeur and his repulsion for their unbridled imperialism. Scott's novels mock the regressively naive and eccentric Roman antiquarianism. He chooses to ascribe fanciful significance to the Antique body-debunked as "antique", in the sense of old, while articulating a more continuous relationship to the past. Guy Mannering and The Antiquary both express a shift from Roman Antiquity to Scottish modernity, which is also a move away from nationalism to focus on humanity. The strong, almost unconquerable body of the nation inherited from the Roman Empire seems to give way to the more perishable and fallible eroticised Scottish human body. Scotland's Roman model is eventually written off to be replaced by Scott's "Caledoniad", a Scottish national epic made up of a fragmented textual body, which Lovel, or Lord Geraldine, from The Antiquary is supposed to be clandestinely writing. Scott has helped create a new form of novel, which, like a patchwork, is made up of Scottish inventions, universal modernity, and fragments from the national past. The Romantic body of "Scott-land" and its vestiges have now been turned into a commodity which modern tourists, enthused by their reading of the Waverley novels, seek to rediscover in Scotland. 
Les romans écossais de Walter Scott témoignent de la volonté romantique typique du $18^{\text {ème }}$ siècle d'exhumer le corps antique de l'Écosse, un corps qui est tout à la fois reconstruit de manière nostalgique car il est marqué par les traces de la conquête romaine, et déconstruit de façon satirique à travers la tension constante entre l'attirance de l'auteur pour la grandeur culturelle et linguistique des Romains et sa répulsion pour leur impérialisme effréné. Les romans de Scott critiquent un attachement régressif au passé romain, à la fois excentrique et naï. Il choisit de donner une signification fantaisiste au corps, dit "antique", au sens de vieux, tout en articulant une relation plus continue avec le passé. Guy Mannering et L'Antiquaire mettent tous les deux en avant la transition de l'Antiquité romaine à la modernité écossaise, qui marque aussi un départ du nationalisme pour se focaliser sur l'humain. Le corps fort et presque invincible de la nation, hérité de l'Empire romain, semble céder en faveur d'un corps «érotique " plus périssable et faillible. Une croix est finalement faite sur le modèle romain de l'Écosse qui est remplacé par la "Caledoniad" de Scott, une épopée nationale écossaise constituée d'un corps textuel fragmenté que Lovel, alias Lord Geraldine, est soi-disant en train d'écrire en secret. Scott a ainsi participé à la création d'une nouvelle forme de roman qui, comme un patchwork, est fabriquée de fragments tirés d'un passé national, d'éléments à la modernité universelle et d'inventions écossaises. Le corps romantique de l'Écosse de Scott et ses vestiges ont été transformés en produits de consommation que les touristes modernes, enthousiasmés par leur lecture des Waverley Novels, cherchent à redécouvrir en Écosse.

\section{INDEX}

Keywords: antiquarianism, antique/ancient Body, nostalgia/ satire, romanticism, Roman Empire, patchwork, novel

Mots-clés: Antiquité, corps antique/ ancien, nostalgie, satire, romantisme, empire romain, patchwork, roman

\section{AUTHORS}

\section{CÉLINE SABIRON}

Senior Lecturer in English Literature / Research Fellow

University of Lorraine / Wolfson College, Oxford

celine.sabiron@univ-lorraine.fr 